\title{
Artisanal Mining, Employment and Empowerment in the North and East of Côte d'Ivoire
}

\author{
Romuald Guédé1, El Hadj Ali Gbané2, Allou Tolla Koffi ${ }^{3}$ \\ ${ }^{1}$ Faculty of Economic Sciences and Management, Université Jean Lorougnon Guédé, LARGE, Daloa, Côte d'Ivoire \\ ${ }^{2}$ Faculty of Economic Sciences and Management, Université Félix Houphouët Boigny, CIRES, Abidjan, Côte d'Ivoire \\ ${ }^{3}$ Faculty of Communication Environment and Society, Geography, Université Alassane Ouattara-Bouaké, CIRES, Bouaké, \\ Côte d'Ivoire \\ Email: jr.guedey@gmail.com, elhadjaligbane@gmail.com, alloutollakoffi@gmail.com
}

How to cite this paper: Guédé, R., Ali Gbané, E.H. and Koffi, A.T. (2019) Artisanal Mining, Employment and Empowerment in the North and East of Côte d'Ivoire. Theoretical Economics Letters, 9, 2914-2939.

https://doi.org/10.4236/tel.2019.98181

Received: August 28, 2019

Accepted: December 10, 2019

Published: December 13, 2019

Copyright (c) 2019 by author(s) and Scientific Research Publishing Inc. This work is licensed under the Creative Commons Attribution International License (CC BY 4.0).

http://creativecommons.org/licenses/by/4.0/

\section{Open Access}

\begin{abstract}
This study aims to analyze the impact of mining activities and the empowerment of women on their involvement in household development. This involvement is perceived through the level of empowerment of women in household. Methodologically, an index of empowerment is designed from methods of inertia. Then, employability of women in artisanal mine is modeled from her characteristics. Finally, a logit model is established to measure factors impacting women's empowerment at household level. It emerges that the level of women's empowerment in her household increases as she earns an income of 60,000 FCFA and more per month. In addition, $66.21 \%$ of women are autonomous at household level. Therefore, it is appropriate to re-examine current conditions of employment of women, without favoring it in less risky or affordable work.
\end{abstract}

\section{Keywords}

Artisanal Mining, Empowerment, Employment, Logit

\section{Introduction}

Côte d'Ivoire is facing a rapid expansion of artisanal mines over the past decade in most of the country. This was made possible by the cession of the country from $2002^{1}$, aggravated by the post-election crisis in 2011. Artisanal mining sector employs approximately 100,000 people directly, of whom 600,000 depend on

${ }^{1}$ Between 2002-2012, the government stops granting mining licenses to mining stakeholders according to PNRO-2014. 
it, specifically in gold and diamond sectors [1]. In countries such as Ghana, Mali, and Burkina Faso, where these activities are heavily practiced, women represent respectively $45 \%, 50 \%$ and $45 \%$ of labor force in artisanal mines [2]. It is estimated between $30 \%$ and $40 \%$, proportion of women practicing in artisanal gold mining in Côte d'Ivoire and 5\% in diamond. Formal mining sector employs about 3000 people, $30 \%$ of whom are women and $23 \%$ to $30 \%$ are in gold sector (PNRO-2014) $)^{2}$. In artisanal mining sector, female workforce accounts for about $50 \%$, with women economically managing their households [3]. From this point of view, it seems that this mining environment is likely to have an impact on economy of this country; major challenge remains rehabilitation and formalization of mining extractive activities. Increasing women's involvement in mining sector by increasing their responsibility and participation in social and political life would make a significant contribution to country's economic growth. Indeed, women tend to play secondary or even lower roles in chain of production and trade in artisanal mines; sometimes excluded for various reasons from decisions that determine the level of payment and organization of mining teams. Yet exclusion from key aspects of economic governance profoundly undermines women's well-being and economy as a whole [4].

In view of severe and recent crisis, women residents of various artisanal mining communities are exposed to higher risks compared to peri-urban dwellers. This is reflected in the fact that informal workers are subject to social, economic and environmental insecurity [4]. Also, in Côte d'Ivoire, in general, artisanal mines represent a tangible short-term opportunity with economic value for men and women. In North and East zones, observation is the same. Sector generates a high potential for economic returns for both men and women. If women's barriers to employability are lifted, which inhibit their empowerment, then their ability to generate a dividend to social and economic cohesion could be increased. However, such a transition cannot be achieved without a deliberate and comprehensive recognition of the role of women working in mining extractive sector.

Several studies dealing with the mining, one approached with all its components (gold, manganese, diamond, gravel, sand, oil, etc.) and/or on a large scale. In examining the participation of women in extractive sector, we distinguish small-scale and large-scale mining. Large-scale mining generally refers to the legal and regulatory activities of large public or private companies. We only considered in the study artisanal and small-scale mining.

A limitation of the study should be weak and/or non-existent data. By promoting data collection (artisanal and industrial) on mining activities in Côte d'Ivoire, Growth Opportunities for Women (GrOW) project corrects some of the data gaps. Another specificity or limitation of the study is related to measuring women's economic empowerment. We distinguish two groups: autonomous

\footnotetext{
${ }^{2}$ National Program for the Rationalization of Gold Mining (PNRO), was decided by government in October 2013, which is a three-year program to deal with uncontrolled expansion of gold panning in almost all regions of country and these adverse effects on physical environment and social fabric. The program was put into effect by decree $\mathrm{N}^{\circ}$ 139/PM/CAB of March 31, 2014.
} 
and non-autonomous when several studies add an intermediate class. This specification is based on the subject of the study.

This paper aims to analyze impact of socio-professional situation in artisanal mining jobs on empowerment of women in North and East zones of Côte d'Ivoire. This is achieved by economic autonomy more representative of woman in her household.

Paper is organized as follows: Section 1 gives an overview of women's access to artisanal mining jobs, employment conditions in this sector and women's empowerment. Section 2 describes methodology and variables used to conduct study. Section 3 presents results of study. Discussion is discussed in Section 4. Paper's conclusion summarizes main findings with policy recommendations.

\section{Literature Paper}

Extraction of natural resources is playing an increasingly important role in economic development strategies of many countries in South. Also, mining takes into account extraction of a wide range of resources including gold, manganese, diamond, gravel, etc. [5]. In examining women's participation in extractive sector, we distinguish between small-scale and large-scale mining. Large-scale mining generally refers to legal and regulatory activities owned by large public or private companies. They are characterized by important investments and require a heavy and advanced technology. Small-scale mining requires excessive and low-skilled labor [6], which employs more women [7].

\subsection{Women and Access to Employment in Artisanal Mining Sector}

According to ILO [8], around 13 million people around world work directly in artisanal mining sector and another 100 million indirectly depend on sector. Globally, women make up nearly 50\% of workforce in sector [9]. Hilson [10] notes that despite some disparities, female labor force is as large as that of men in many countries.

In general, artisanal mines often involve all members of same household, with women playing different roles. In a direct way, they work either as service providers or in extraction of minerals. Indirectly, they occupy domestic work, which depends on local cultural configurations. For example, in Asia, less than $10 \%$ of individuals working in the mining extractive sector are women. In Latin America, they are around 20\%. In Asia and Latin America, women make up $70 \%$ and $50 \%$ of labor force in sector, respectively [11]. It is in Africa that there is a significant number of women working in sector with $40 \%$ to $50 \%$. In some localities in Africa, there is between $60 \%$ and $100 \%$ participation of women in artisanal mining sector. In Guinea, about $74 \%$ of small-scale miners are women, in Madagascar, Mali and Zimbabwe they represent 50\% of artisanal mining workforce [10].

Women in developing countries are almost involved in entire mining process; transportation and processing of ore, excluding exploitation of underground 
mines. Indeed, in many African countries, women are seen as bad luck when they enter underground mines [11]. However, despite large number of women engaged in artisanal mining sector in developing countries, some authors highlight historical and ongoing invisibility of women in small-scale mining and artisanal mining [3] [13].

However, we realize that in the sector, some women are enterprising. They have a wide range of activities either forward or backward. The latter may own farm sites holding mining equipment. They can still act as ore brokers, etc. Despite this finding, overall, they appear to be few in number [14] Also, many authors note that because of informal nature of women's work in this sector, their status as minors is not recorded or recognized [7].

According to Hinton and al [15], women's participation in sector can have a significant impact on agricultural production and even food shortages [15]. This massive participation of women in artisanal mining is often due to drought, loss or destruction of arable land, natural disasters, etc. [3].

A large proportion of women work in artisanal mining sector while being head of household. For them, extraction of ore is sometimes the only economic activity [16]. In addition, these women are often present in sector on a seasonal basis, or at times of economic difficulty [7]. Under these conditions, they are likely to perform at same time several different productive tasks, which leads them to be overexploited and overloaded [17].

In literature, a contrast remains. While women are strongly represented in artisanal mining sector, it is sad to note that they are at bottom of job ladder, where they perform the most dangerous tasks [12]. In this environment, it is necessary to browse working conditions of women in artisanal mining sector.

\subsection{Conditions of Employment in Artisanal Mining Sector}

Several studies and development initiatives to improve conditions of employment in artisanal mining sector have rarely been of interest to women [3].

Women working in artisanal mining sector are generally required to perform heavy and sometimes dangerous work. They are responsible for ore processing, crushing, grinding, etc. In gold panning, they are constantly exposed to mercury or cyanide in ore treatment process to separate it from tailings [3]. According to Jenkins [5], these women in sector have the lowest earnings and yet they have a high volume of manual labor.

Women in the operation of artisanal mine perform many tasks. Either they are traders given presence of the mine, or women and girls prostitute themselves. In addition, when a woman is known to have belonged to sex industry, her reintegration into her community or family becomes almost difficult [4].

Given arduous nature of sector, there is a lack of expertise and engineering. There are also numerous accidents on exploitation sites, which generally come from landslides, rock falls, lack of air in holes, mishandling of machines and explosives, lack of appropriate equipment [7]. Again, women assume the responsi- 
bility of being primary caregivers or first responders in event of an incident, as primary caregiver of their family's health [5].

In many countries, women support many dependents through many and varied activities they carry out either directly or indirectly in connection with artisanal mining [4]. But there is a pay inequity between men and women in the sector. Women's pay is significantly lower than that of men. Gender disparities exist with respect to access to employment, type of employment offered, etc. and are generally marginalized in their community regarding decision-making.

In short, we have a rather gloomy picture of women's participation in artisanal mining sector, characterized by vulnerability and lack of autonomy. Also, informal nature of sector exposes these women to manual work marked by a certain difficulty of execution, dangerousness, non-regulation, etc. [18].

However, it is good to know that women working in sector are not all victims, because some are really enterprising, resilient, etc. [19]. For women to benefit more from artisanal mining, it seems first imperative to increase visibility of their production work, and then to make it heard [7].

\subsection{Women's Empowerment}

Empowerment refers to women's acquisition of resources and abilities, as well as their ability to act in a context of gender inequality [20]. It is also expansion of choices given to women so that present results reflect choices for which they attaches importance [21]. Moreover, it is further increasing possibilities of choice and opportunities that allow them to have more control over their life, better reach ability to live existence of their choice [22].

If empowerment of women is a latent phenomenon that is difficult to observe, it could be understood through access to media and communication, economic security, education, legal awareness, etc.

Indeed, empowerment of women is a multidimensional approach composed of six dimensions (economic, socio-cultural, family, legal, political and psychological). Also, the contextual approach of definition extends to household, community, region, country, etc. [23]. We retain in this article economic empowerment of women at the household level.

To this end, we design an indicator of economic empowerment based on work of [23]. Economic empowerment of women is then measured first at household level, based on a number of points about their ability to control household income, relative contribution or household support, access to resources household or their control. Second, at community level based on women's access to employability, ownership of assets and land, participation or representation in a local trade association, access to markets.

Development is understood in our context as ability to mobilize resources and use them while preserving gains for future generations. Also, use of resources alludes to their use, therefore to the working mechanism that leads to improvement of living conditions. Thus, when women are given work opportunities, they will 
contribute intrinsically to development of their community.

Indeed, autonomy of women at community level necessarily implies that they are active or that they participate in community development of their locality, insofar as, when they acquire a certain economic autonomy, it meets objectives of community development of women (FAD $\left.{ }^{3},[24]\right)$.

\section{Methodology}

\subsection{Data and Choice of Variables}

Data in this study come from a survey conducted in ten (10) mining-intensive regions in Côte d'Ivoire. It is a two-stage sample survey of households living in artisanal mining areas.

In first step, target areas are selected by drawing with unequal probabilities. In second stage, a simple random sampling of target households is conducted in selected villages. In total, 20 localities were surveyed across ten (10) regions surveyed. In each household drawn, only one individual is selected if household size is 1 , otherwise at least two target individuals are interviewed. Sample includes 1842 individuals, 1197 of whom are in artisanal mining sector. Units are selected by simple random sampling. Technical implementation of this survey is carried out by Ivoirian Center for Economic and Social Research (CIRES), with financial support from the International Development Research Center (IDRC). In this study, we limit ourselves to four (4) regions in northern and eastern zones (see Appendice 1 and Appendice 2). Data include household characteristics, employment characteristics, social cohesion, women's empowerment, and agricultural transitions. They provide all information resources needed to carry out this research work.

Variables used for the various analyzes derive from objectives assigned to them. Indeed, variables used to analyze employability of women in extractive sector are place of residence (urban, rural), age grouped into classes (under 25, 25 - 34, 35 and over) migration status (Being a migrant, Being a non-migrant), schooling (yes, no) and household head status [25] [26] [27]. At this level, variable of interest is being employed in artisanal mining sector. To measure economic empowerment, the situation of economic empowerment at household level was considered. Economic empowerment of women within household is perceived by the fact that they can control use of household income, contribute to household expenses, and generally access or control all household income or family resources [23]. It is this dimension that is used to build empowerment index (at household level).

Regarding analysis of women's empowerment at community level, the variables used relate to the conditions of employment. These are: wage compensation, work safety, work hardness, socio-professional category, payment method of remuneration, workload through the number of weekly hours of labor, recruitment channels, employment sustainability prospects and the type of contract [28].

${ }^{3}$ Fond Africain de Developpement. 


\subsection{Analytical Methods}

In this sub-section we present the specific approach related to construction of women's empowerment index and econometric regressions that favored estimation of employment determinants in artisanal extractive sector, as well as those empowerments of women in household.

\subsection{Construction of Economic Empowerment Index}

Economic empowerment index is developed using inertia methods [29] [30] [31]. They correspond to factorial analysis methods combined with Hierarchical Ascending Classification (CAH). This approach is relevant insofar as one is in presence of more than three active variables. Also, it allows to grant relatively more objective importance to the different dimensions coming online in construction of indicator. As a factor analysis method, Multiple Correspondence Analysis (MCA) was used.

In a technical way, implementation of these methods starts from construction of factorial axes. Then, we proceed to formation of optimal factorial plan, on basis of the choice of two factorial axes based on Kaiser criteria and cumulative percentage. In addition, the best score is chosen from cut of dendrogram. Finally, we interpret and label the different classes from CLA/MOD and MOD/CLA indicators for representative attributes. At the end of operation, the different classes are archived to obtain indicators of empowerment.

\subsection{Specification of the Econometric Model}

The logit model is commonly used in economics. The explained variable is qualitative because it only takes a finite number of modalities. So, the individual data of the study lend itself easily to the use of such a method.

In this section, the explained variable includes two modalities (dichotomous model). For example, being employed or not in the artisanal mining sector is specified by: $Y_{i}=1$ if the person $i$ works in the artisanal mining sector and $Y_{i}=0$ otherwise.

As specified, the selection of explanatory variables to build the econometric model is based on economic fundamentals. Thus, the probability that the dependent variable will be 0 or 1 , assumes that there is a latent variable $Y_{i}^{*}$ such as:

$$
Y_{i}=\left\{\begin{array}{l}
1 \text { if } Y_{i}^{*} \succ 0 \\
0 \text { if not } Y_{i}^{*} \prec 0
\end{array}\right.
$$

Then, we assume that this latent variable $Y_{i}^{*}$ is linearly dependent on a number of explanatory variables $X_{i}$ :

$$
Y_{i}^{*}=X_{i}^{\prime} \beta+\mathrm{E}_{i}
$$

where interestvariable is $Y_{i}, X_{i}$ is explanatory variables of the model, $\beta$ is estimated parameters of the model and the error term $\varepsilon_{i}$ follows logistic law. 
F(.) denotes a distribution function. So, we call logistic model, the dichotomous model which admits for distribution function the distribution function of logistic law given by:

$$
F(x)=\frac{\exp (x)}{1+\exp (x)}=\frac{1}{1+\mathrm{e}^{-x}}
$$

Estimates use the maximum likelihood method. In the logit model, log likelihood is concave in $\beta$ and the likelihood equations are necessary and sufficient conditions. Information about tests of significance, coefficient interpretations and ratios are recorded in the table of different results.

\subsection{The Artisanal Mining Sector Employability Modeling}

Estimating the employment determinants of the artisanal mining sector is done by a logit model [32] [33] [34] [35]. The variable of interest is:

$$
\left\{\begin{array}{l}
Y_{i}=1 \text { if the person works inartisanal mining sector } \\
Y_{i}=0 \text { if not }
\end{array}\right.
$$

$Y_{i}$ is interest variable of being employed in artisanal mining sector and $Y_{i}$ is modeled by latent variable approach. The explanatory variables are individual characteristics of woman described above.

This modeling is needed to generalize results to all individuals. It makes it possible to reproduce objectively representativity of extractive sector within population. In practice, at the end of modeling, we have recovered predicted value of probability for each individual to work in the sector. Then, the inverse of this probability was used as weighting value in regression. This precaution offers the advantage of working as if one were with individuals employed exclusively in artisanal mining sector.

\subsection{Empowerment Determinants Estimation in Household}

In addition to the autonomy of woman in household, modeling identifies other factors likely to increase employment opportunities for women in artisanal mining sector. This necessitated use of logistic regression [36] [37] [38]. Interest variable is:

$$
\left\{\begin{array}{l}
Y_{i}=1 \text { if the person is automous at household level } \\
Y_{i}=0 \text { if not }
\end{array}\right.
$$

where $Y_{i}$ is the index of economic empowerment of women at household level. More specifically, the indicator takes into account income control, land ownership, contribution to family support, access and control of family resources [3]. The explanatory variables are working conditions i.e. pay, work safety, hardness of work, socio-occupational category, method of remuneration, volume of work (number of hours per week of labor), recruitment channels, employment sustainability prospects and type of contract [28]. 


\subsection{Verification and Robustness of Model}

Diagnose a logistic model is to determine the fit of model to data. Thus, like Pearson, we analyze residuals that make it possible to rule on the existence or not of observations poorly adjusted having a significant potential effect on estimation of coefficients. Evaluation of model's ability to discriminate terms of interest variable was done from sensitivity and specificity curves, and ROC curve (Receiving Operating Curve). But, before looking at the residuals, it is important to evaluate the calibration of the model.

Hosmer-Lemeshow test [39] compares predicted and observed values of modalities of interest variable, after grouping individuals into classes. The Chi-square distance is then used to calculate the difference between observed and predicted frequencies. If this distance is relatively small, then the model is well calibrated. In our study, this test shows that overall fit of the model to data is satisfactory (See Table 2 and Table 3 ). Indeed, the value of critical probability (Prob $>$ chi2) is greater than threshold of significance of $5 \%$.

The ROC curve is used to evaluate and compare model performance from graphical information. It represents sensitivity according to specificity. While we usually compare predictions to a threshold value called medium (threshold $=$ $0.5)$, ROC curve makes it possible to generalize this idea by varying the threshold between 0 and 1. For each threshold value, a new confusion matrix is constructed, giving sensitivity and specificity. It is characterized by a numerical indicator that corresponds to area between the two curves drawn. This indicator is named AUC (Area Under Curve). Values taken by the AUC are interpretable. According to [40], the different ROC curves obtained for the two estimates respectively show that discrimination is acceptable and excellent. For the model prediction table see Appendices 4-5 (description of the variables used in the study) and 6 (Test Pearson or Hosmer-Lemeshow goodness-of-fit test), where results are all conclusive.

Residue analysis indicates that an observation is poorly explained when value of associated Pearson residue is greater than 2. They become suspicious when their number exceeds $5 \%$ of all observations. In the first estimate, 25 observations out of 367 presented extreme residues. In the second estimate of $3247 \mathrm{ob}-$ servations, 170 have extreme tailings (see Appendix 6).

\section{Results}

\subsection{Measuring Women's Economic Empowerment}

In order to measure women's empowerment, paper developed an indicator of economic empowerment, calculated at household level. It is an index that captures role and participation of women in the development of their immediate environment. Drafting consisted technically in three (03) specific stages: first, calculation of eigenvalues and choice of factorial axes, and then the choice of optimal partition and finally, description of classes. Decision criterion is based on histogram of eigenvalues which makes it possible to retain, for each of measures 
of empowerment, the first two factorial axes. In both cases, they verify the Kaiser criterion because their eigenvalues are all higher than average of eigenvalues (Appendix 3). In addition, the two factorial axes accumulate $60 \%$ of inertia, after correction of eigenvalues, indicating a high concentration of inertia at these two axes. In addition, representation of dendrograms recommends keeping scores in two classes for each of two indicators ${ }^{4}$.

Results of classification in Table 1, show that level of economic empowerment is relatively high at household level. This demonstrates the strong dynamism of women as well in economy as harmonious development of households. As proof, $66.21 \%$ of women are economically autonomous in their respective households. As a result, economic position of women in their households has a direct impact on their community environment.

Determinants of employment in artisanal mine

Table 2 shows that socio-demographic characteristics determine employment of women in artisanal mining sector. Jobs in artisanal mining sector are more accessible to people living in rural areas. Residing in rural areas increases probability of women working in artisanal mines by $46 \%$. Specifically, a woman residing in rural areas is 57 times more likely to be employed in artisanal mining sector than another resident in urban areas. In addition, these jobs are more accessible to older women. Schooling reduces opportunities for women to work in artisanal mining sector. Being an educated woman decreases probability of getting a job in artisanal mining sector by $21.1 \%$. Working in artisanal mining sector requires, to a certain extent, more sense of responsibility. As a result, being a female head of household increases probability of working in artisanal mining sector by $22.9 \%$. Migration status of women has no impact on employability in artisanal mining sector.

\subsection{Role of Women in Household Development}

The results in Table 3 show that the women's empowermentis first apprehended through sums of money she receives from extractive activity and then by local community's perception of women's mining activity.

In practical terms, resources from extractive activities enable women to build socially while effectively contributing to household life, including spending. These amounts help to meet challenges of household and achieve achievements. A woman's ability to provide herself with opportunities and benefits of community, exploited on an artisanal basis, depends mainly on characteristics of job and its status of economic autonomy. Indeed, to be economically independent, woman will have to earn at least 60,000 FCFA per month (first quintile). Earning CFAF 60,000 or more increases probability of being economically self-sufficient within household by $12.7 \%$. Results show that the more one tends towards fifth quintile, the better probability of being economically autonomous in household is high. Earning at least CFAF 120,000, CFAF 156,000 and CFAF 450,000 
Table 1. Information on women's empowerment in north and east mining regions in Côte d'Ivoire.

\begin{tabular}{cccc}
\hline Empowerment of woman in her household & Frequencies & Percentage & Cumulative percentage \\
\hline Not autonomous & 124 & 33.79 & 33.79 \\
Autonomous & 243 & 66.21 & 100 \\
\hline
\end{tabular}

Source: CIRES/CRDI - GROW 2016.

Table 2. Estimated results on determinants of employment in mining sector.

\begin{tabular}{|c|c|c|c|c|}
\hline Explanatory variables & Coefficient & Odds ratio & $\begin{array}{c}\text { Marginal } \\
\text { effects }\end{array}$ & $\begin{array}{c}\text { Standard deviation } \\
\text { \& significance }\end{array}$ \\
\hline \multicolumn{5}{|c|}{ Residence - Reference: Urban } \\
\hline Rural & 3.241 & 25.547 & 0.461 & $0.568^{\star \star *}$ \\
\hline \multicolumn{5}{|c|}{ Age Range - Reference: Under 25} \\
\hline $25-34$ years & 0.280 & 1.323 & 0.037 & 0.486 \\
\hline 35 years and over & 0.851 & 2.341 & 0.131 & 0.535 \\
\hline \multicolumn{5}{|c|}{ Head of Household Status - Reference: No } \\
\hline Oui & 1.523 & 4.867 & 0.229 & $0.552^{\star * *}$ \\
\hline \multicolumn{5}{|c|}{ To be educated - Reference: No } \\
\hline Oui & -1.705 & 0.182 & -0.211 & $0.365^{* * *}$ \\
\hline \multicolumn{5}{|c|}{ Migration status - Being non-migrant } \\
\hline Being migrant & -0.305 & 0.737 & -0.046 & 0.434 \\
\hline Constant & -0.233 & 0.792 & & 0.616 \\
\hline \multicolumn{3}{|c|}{ Number of observations } & \multicolumn{2}{|r|}{367} \\
\hline \multicolumn{2}{|c|}{ Overall significance } & & \multicolumn{2}{|c|}{$\operatorname{LR}-\operatorname{Chi} 2(6)=65.82^{\star * *}$} \\
\hline \multicolumn{2}{|c|}{ Pseudo-R2 } & & \multicolumn{2}{|r|}{$16.99 \%$} \\
\hline \multicolumn{2}{|c|}{ Log-likelihood } & & \multicolumn{2}{|r|}{-160.792} \\
\hline \multicolumn{2}{|c|}{ Hosmer-Lemeshow test } & & \multicolumn{2}{|c|}{ Chi2 $(18)=64.81^{* * *}$} \\
\hline
\end{tabular}

${ }^{* * *}$ significatif à $1 \%,{ }^{* *}$ significatif à $5 \%,{ }^{* * *}$ significatif à 10\%. Source: CIRES/CRDI - GROW 2016.

increases probability of being autonomous at household level by $13.3 \%, 17.2 \%$ and $21.1 \%$ respectively. Moreover, not being a cadre diminishes chances for woman to be economically autonomous at level of her household. This confirms positive link between education and emancipation of women.

Improving capacity and autonomy of woman at household level when working in artisanal mining sector necessarily requires a review of her salary, guaranteeing her safety at work and examining arduousness of her job. Wage compensation would be better by day, not on basis of gold recovery. In other words, woman should not be treated as a mere worker, or even assigned only to support jobs. Employment must guarantee a woman's safety, preserve her health and her physical integrity.

Although women do not feel safe at work, it increases probability of being economically autonomous at household level by $11 \%$. Jobs acquired through 
Table 3. Estimation of impact of mining activities on empowerment.

\begin{tabular}{|c|c|c|c|c|}
\hline Explanatory variables & Coefficient & Odds Ratio & $\begin{array}{c}\text { Marginal } \\
\text { effects }\end{array}$ & $\begin{array}{l}\text { Standard deviation } \\
\text { \& significance }\end{array}$ \\
\hline \multicolumn{5}{|c|}{ Quintile of income - Reference: First quintile } \\
\hline Second quintile & 0.954 & 2.596 & 0.175 & $0.127^{* * *}$ \\
\hline Third quintile & 1.671 & 5.319 & 0.267 & $0.133^{\star \star \star}$ \\
\hline Fourth quintile & 0.553 & 1.739 & 0.101 & $0.172^{* * *}$ \\
\hline Fifth quintile & 4.099 & 60.306 & 0.448 & $0.211^{* * *}$ \\
\hline \multicolumn{5}{|c|}{ Feeling safe at work - Reference: Yes } \\
\hline No & 1.213 & 3.362 & 0.239 & $0.110^{* * *}$ \\
\hline \multicolumn{5}{|c|}{ Work Penalty - Reference: Pénible } \\
\hline Affordable & 2.181 & 8.858 & 0.284 & $0.227^{\star * *}$ \\
\hline \multicolumn{5}{|c|}{ Socioprofessional category - Reference: Cadre } \\
\hline Intermediate professions & -2.921 & 0.054 & -0.620 & $0.472^{\star * *}$ \\
\hline Employee & -2.342 & 0.096 & -0.311 & $0.474^{* * *}$ \\
\hline \multicolumn{5}{|c|}{ Frequency of payment of remuneration - Reference: pro rata of the profit } \\
\hline $\begin{array}{l}\text { According to the quantity of } \\
\text { production }\end{array}$ & 0.031 & 1.032 & 0.006 & 0.115 \\
\hline Per day & 1.273 & 3.573 & 0.211 & $0.178^{* * *}$ \\
\hline Per month & -0.115 & 0.891 & -0.024 & 0.182 \\
\hline HMOD & 0.009 & 1.009 & 0.002 & $0.003^{* * *}$ \\
\hline \multicolumn{5}{|c|}{ Source of supply Information - Reference: Non-Nobody } \\
\hline Parents/Family/Friends & 0.479 & 1.615 & 0.106 & $0.184^{* * *}$ \\
\hline \multicolumn{5}{|c|}{ Type of contract - Reference: Verbal } \\
\hline Written & -1.688 & 0.185 & -0.379 & $0.190^{* * *}$ \\
\hline non contract & -0.583 & 0.558 & -0.119 & $0.119^{* * *}$ \\
\hline Constant & 0.779 & 2.180 & & 0.510 \\
\hline Number of observations & & \multicolumn{3}{|c|}{3247} \\
\hline Overall significance & & \multicolumn{3}{|c|}{ LR - Chi2 $(15)=1293.69^{* * *}$} \\
\hline Pseudo-R2 & & \multicolumn{3}{|c|}{$29.96 \%$} \\
\hline Log-Likelihood & & \multicolumn{3}{|c|}{-1512.3548} \\
\hline Hosmer-Lemeshow test & & \multicolumn{3}{|c|}{ Chi2 $(154)=5203.52^{\star * *}$} \\
\hline
\end{tabular}

${ }^{* * *}$ significatif à $1 \%,{ }^{* *}$ significatif à $5 \%,{ }^{*}$ significatif à 10\%. Source: CIRES/CRDI - GROW 2016.

family or with support of relatives or friends should be privileged. In addition, employment contracts should be based on trust and oath, without being overly restrictive. In fact, written contracts reduce women's economic empowerment at household level by $19 \%$. When his workload increases by 1 , probability of being autonomous at community level increases by $0.3 \%$.

It appears that empowerment at household level depends on woman's personal will, but also on existing employment regulations, which are instituted by community leaders. From then on, woman will have to be able to work more according to her physical, psychological and mental capacities. This precaution 
has effect of improving its income level, but also its volume of working hours.

\section{Discussions}

Empowerment multidimensional approach, is difficult to conceptualize. Nevertheless, it can be apprehended in different ways mainly depending on objectives that we set ourselves. A number of recent works on empowerment of women have been conducted, especially in mining industry, including Tolonen [41]. In her work, she developed a three-dimensional empowerment indicator at household level (barriers to access to health care, attitudes about domestic violence and gain and decision-making power). Its results show that in mining communities, $23 \%$ of women are less likely to have access to health care and $20 \%$ are less likely to accept domestic violence. In addition, they have no decision-making power in household, as result is not significant. Our modeling estimates that if woman is economically autonomous at household level, then she has decision-making power. This could have a favorable developmental effect within his community.

Beaman and al. [42] find that in areas where no woman has ever been a leader in her household or community, $86 \%$ of parents want their daughters to be housewives. Also, an increase in women's income of $\$ 7$ per month translates into a $1 \%$ increase in survival rate for girls, when a child's policy is a strong determinant of boys' preference in China [43]. Similarly, our results show that around $66.21 \%$ of women are economically self-sufficient at household level. This large proportion of self-sufficient women leads to reconsidering their role in households in our study ${ }^{5}$ area.

Here we are not going to talk in terms of survival of girls like in China, but rather of fulfillment. A woman is considered economically self-sufficient in her household when she earns an income of CFAF 60,000 or more. As this income increases, girls will be able to go to school and have a better future. Financial resources of mining activity allow women to take care of children and help spouses. This provision offers them opportunity to face same challenges as men in Gontougou, promotes rebalancing of family power.

In north of country, situation is more delicate because of cultural and religious factors. Nevertheless, income from the activity encourages strengthening of community life, allowing women through their representatives to make decisions of a community nature during major meetings. Women's association office members are considered to be involved in community leadership.

An autonomous woman is one who is able to take charge of a financial point of view and to support all or part of household expenses. These are, among other things, schooling, child health, work in countryside, etc.

Results of our estimates indicate that residing in rural areas increases probability of women working in artisanal mine by $56.8 \%$. To this end, literature states that mining as a whole tends to be in remote rural areas. Also, does it lead

${ }^{5}$ Regions of study are still heavily inked in traditionalism; the woman must be at home. 
to widespread social change, whether it is advent of new communities as people migrate to work in the mine or process of transformation of resident communities in rural areas that host mines [5]. Women make up almost 50\% of global workforce in sector [9]. These theses support our results, which show that women in rural areas are 25 times more likely to work in mining sector.

In general, probability of working in informal mining sector decreases with age. Adair and Bellache [44] show that entrepreneurs aged 30 to 39 are half as likely to be informal as those aged 20 to 29 . Those aged 40 to 49 are five times less likely to be informal. In our study, the fact that women are over 15 years of age does not have significant effects on their household empowerment. Indeed, cultural and religious factors in North of country are such that, girl is early married, after being forced to drop out of school. As a result, she is soon confronted with world of work. As artisanal mining sector is unregulated, apart from a few mining communities that organize themselves into a mining cooperative, trust and a sense of responsibility necessarily influence the role of women in sector. As proof, Hayes and Perks [4] show that women are allowed to handle gems because they are credible to site managers. Although these examples are unique, they provide potential models for improving situation of women in sector.

Fundamentally, artisanal mining sector brings together people who practice in informal and/or illegal [27]. Our results indicate that an educated woman sees her probability of working in artisanal mining sector decrease by $21.1 \%$. This is justified by the fact that having a high level of education actually reduces probability of working in informal sector [45] [46].

Education and life expectancy of women in household are discriminating factors of working conditions in specifically gold-bearing artisanal mines [28]. This justifies low level of education of women in sector. People with more education are likely to live longer and work in a safe and secure environment. A high level of education generally suggests such a high probability of being employed and therefore having a job with healthier working conditions, better work benefits and higher wages [47].

Our results indicate that in artisanal mining sector, if woman's workload increases by one unit, her probability of being self-sufficient at household level increases by $0.3 \%$. In addition, women earn less than men for the same work and are therefore more likely to be poor. They spend almost twice as much time doing housework, almost five times as much child care time, and about half as much working time as men [48]. This implies that to be autonomous in one's household or in artisanal mining community, woman will have to devote more time to work. In doing so, she can hope to see her income grow and reach at least FCFA 60,000 per month, which increases by $12.7 \%$ her probability of being economically autonomous at household level. She must have SMIG (set at FCFA 60,000 in Côte d'Ivoire) to hope to be economically autonomous while being confined to hard work, dangerous and low pay.

There is evidence in literature of positive link between education, productivity and pay level. This shows that female executive has a certain autonomy. There is 
therefore a positive link between education and gender equality. Indeed, multi-tasking women, with multiple capacities, quick to perform tasks in artisanal mining sector as well as in household and community, if they benefit from assistance could be vectors of local development.

\section{Conclusions and Suggestions}

Artisanal mining sector is growing disproportionately in Côte d'Ivoire. This happens without political decision-makers being able to pin down the effect of the phenomenon on environment, on mining communities, as well as on future generations. In this work, we wanted to provide information on well-being of women with regard to expansion of artisanal mines in northern and eastern regions of Côte d'Ivoire. Our analysis contributes to the understanding of a broader question: Can artisanal mining affect involvement of women in development of family life?

We have shown that $66.21 \%$ of women are self-reliant at household level. A woman is autonomous in her household when she can have a minimum of FCFA 60,000 per month. This reflects barriers that they face in sector. They must have the status of a cadre to hope to be self-sufficient. In this case, they should give more hours of work in a low mechanized and archaic environment, in addition to family charges.

For this purpose, economic empowerment in community is a function of woman's personal will, efforts of community leaders and competent authorities to regulate employment. It is important that sector be regulated for welfare of women. To do this, regulations must ensure a safe, healthy and fair working environment for all. This regulation should take into account compliance with terms of employment contract and more attractive remuneration for women. It is appropriate to create a work environment favorable to woman, so that she expresses herself more in her activities, by her physical, psychological and mental capacities. This will impact his remuneration and hours of work, in order to improve his well-being. We must prohibit gender-based wage disparities in regulation. Of course, our results show that despite the fact that woman does not feel safe in sector, she manages to be self-sufficient ${ }^{6}$ in her home.

Although extractive activity has a positive impact on women's empowerment, this status of an autonomous woman can be a source of disintegration of the woman's integrity, disintegration of family unit. Indeed, mining activities are demanding in terms of physical effort. Sites are sometimes far from woman's place of residence, which may force her to live, sometimes far from family. Therefore, she is more vulnerable to risks of theft, rape, fights, etc. frequent on mining sites [49] [50]. Also, working on the mine sites forces her to move away from her role as an educator, causing phenomenon of child labor. Latter for subsistence needs and maternal protection follow their mother on sites [51].

In addition, in order to improve their income, activity of women in artisanal

${ }^{6}$ There is a positive relationship between lack of security and empowerment of women in their households. 
mining can be a barrier to schooling for children. It is therefore necessary for policymakers and key players in mining sector to understand the role of women in mining sector in order to strengthen it [52]. Then, it is appropriate to realize a set of social infrastructures (schools, health centers, etc.) close to exploitation sites to reduce risks of insecurity, prostitution, epidemics, etc. On the other hand, this is only possible if artisanal mines acquire formal status [53] and operate within a legal framework.

In sum, despite concerns about wage disparities, discrimination and conditions of employment between men and women, the study argues that artisanal mining improves women's well-being. Thus, policy-makers would benefit from undertaking policies that could regulate mining environment, to enable women to benefit more from mining activities.

Specifically, policymakers should solve problem of illegal logging by raising awareness, eliminating corruption and lawlessness in sector, by issuing licenses for small artisanal mines for men and women organized in cooperatives.

\section{Acknowledgements}

This work was carried out at part of the Growth and Economic Opportunities for Women (GrOW) program with financial support from the UK Government's Department for International Development, the William and Flora Hewlett Foundation, and the International Development Research Centre, Canada.

\section{Conflicts of Interest}

The authors declare no conflicts of interest regarding the publication of this paper.

\section{References}

[1] Hilson, G. (2016) Artisanal and Small-Scale Mining and Agriculture: Exploring Their Links in Rural Sub-Saharan Africa. IIED, London.

[2] Hentschel, T., Hruschka, F. and Priester, M. (2002) Global Report on Artisanal and Small Mining, Minerals Mining and Sustainable Development (MMSD) Project. International Institute for Environmental Development, London.

[3] Hinton, J.J., Veiga, M.M. and Beinhoff, C. (2003) Women and Artisanal Mining: Gender Roles and the Road Ahead. In: Hilson, G., Ed., The Socio-Economic Impacts of Artisanal and Small-Scale Mining in Developing Countries, Swets Publishers, Netherlands, 149-188.

[4] Hayes, K. and Perks, R. (2012) Women in the Artisanal and Small-Scale Mining Sector of the Democratic Republic of the Congo. In: Lujala, P. and Rustad, S.A., Eds., High-Value Natural Resources and Peace Building, Earthscan, London, 529-542.

[5] Jenkins, K. (2014) Women, Mining and Development: An Emerging Research Agenda. The Extractive Industries and Society, 1, 329-339. https://doi.org/10.1016/j.exis.2014.08.004

[6] Hilson, G. and McQuilken, J. (2014) Four Decades of Support for Artisanal and Small-Scale Mining in Sub-Saharan Africa: A Critical Review. The Extractive In- 
dustries and Society, 1, 104-118. https://doi.org/10.1016/j.exis.2014.01.002

[7] Lahiri-Dutt, K. (2008) Digging to Survive: Women's Livelihoods in South Asia's Small Mines and Quarries. South Asian Survey, 15, 217-244.

https://doi.org/10.1177/097152310801500204

[8] International Labour Organization (ILO) (1999) Social and Labour Issues in Small-Scale Mines. Report for Discussion at the Tripartite Meeting on Social and Labour Issue in Small-Scale Mines. International Labour Organisation, Sectoral Activities Programme, Geneva.

http://www.ilo.org/public/english/dialogue/sector/techmeet/tmssm99/tmssmr.htm

[9] Macdonald, C. (2017) The Role of Participation in Sustainable Community Development Programs in the Extractives Industries. UNU-WIDER.

[10] Hilson, G. (2002) Harvesting Mineral Riches: 1000 Years of Gold Mining in Ghana. Resources Policy, 28, 13-26. https://doi.org/10.1016/S0301-4207(03)00002-3

[11] Hruschka, F. and Echavarria, C. (2011) Rock-Solid Changes for Responsible Artisanal Mining. Alliance for Responsible Mining, Medellin.

[12] Van Hoecke, E. (2006) The Invisible Work of Women in the Small Mines of Bolivia. In: Lahiri-Dutt, K. and Macintyre, M., Eds., Women Miners in Developing Countries: Pit Women and Others, Ashgate Publishing, Aldershot, 265-288. https://doi.org/10.4324/9781315233734-14

[13] Orozco Zevallos, O. (2013) Invisible and Informal: Women Artisanal Gold Miners. Peru Support Group. http://perusupportgroup.org.uk/article-640.html

[14] Maconachie, R. and Hilson, G. (2011) Artisanal Gold Mining: A New Frontier in Post Conflict Sierra Leone? The Journal of Development Studies, 47, 595-616. https://doi.org/10.1080/00220381003599402

[15] Hinton, J.J., Hinton, B.E. and Veiga, M.M. (2006) Women in Artisanal and Small Scale Mining in Africa. In: Lahiri-Dutt, K. and Macintyre, M., Eds., Women Miners in Developing Countries: Pit Women and Others, Ashgate Publishing, Aldershot, 209-226. https://doi.org/10.4324/9781315233734-11

[16] Chaparro Avila, E. (2005) La mujer en la pequena minerı de America Latina: El caso de BoliviaCEPAL.

http://www.cepal.org/cgibin/getProd.asp?xml=/publicaciones/xml/4/21214/P21214.

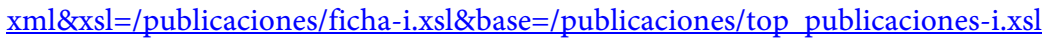

[17] Macintyre, M. (2006) Women Working in the Mining Industry in Papua New Guinea: A Case Study from Lihir. In: Lahiri-Dutt, K. and Macintyre, M., Eds., Women Miners in Developing Countries. Pit Women and Others, Ashgate Publishing, Aldershot, 131-144. https://doi.org/10.4324/9781315233734-7

[18] Bhanumathi, K. (2009) The Status of Women Affected by Mining in India. In: Macdonald, I. and Rowland, C., Eds., Tunnel Vision: Women, Mining and Communities, Oxfam Community Aid Abroad, Fitzroy, 20-24.

[19] Werthmann, K. (2009) Working in a Boom-Town: Female Perspectives on Gold Mining in Burkina Faso. Resources Policy, 34, 18-23.

https://doi.org/10.1016/j.resourpol.2008.09.002

[20] Schuler, R.S. and Tarique, I. (2010) Global Talent Management: Literature Review, Integrative Framework, and Suggestions for Further Research. Journal of World Business, 45, 122-133. https://doi.org/10.1016/j.jwb.2009.09.019

[21] Kabeer, N. (2001) Reflections on the Measurement of Women's Empowerment. In Discussing Women's Empowerment-Theory and Practice. Sida Studies No. 3. Novum Grafiska AB, Stockholm. 
[22] Mahmud, S., Shah, N. and Becker, S. (2012) Measurement of Women's Empowerment in Rural Bangladesh, World Development, 40, 610-619.

https://doi.org/10.1016/j.worlddev.2011.08.003

[23] Malhotra, A., Schuler, S.R. and Boender, C. (2002) Measuring Women's Empowerment as a Variable in International Development. World Bank Workshop on Poverty and Gender: New Perspectives.

[24] FAD (2003) Ghana: Projet de développement communautaire au profit des femmes.

[25] Boskin, M.J. (1974) A Conditional Logit Model of Occupational Choice. Journal of Political Economy, 82, 389-398. https://doi.org/10.1086/260198

[26] Lassassi, M. and Muller, C. (2014) Salaires, Genre et choix de secteurs en Algérie. In Economic Research Forum, Working Paper 853.

[27] Kotsadam, A. and Tolonen, A. (2015) African Mining, Gender, and Local Employment. The Word Bank Group. https://doi.org/10.1596/1813-9450-7251

[28] Armah, F.A., Boamah, S.A., Quansah, R., Obiri, S. and Luginaah, I. (2016) Working Conditions of Male and Female Artisanal and Small-Scale Gold Miners in Ghana: Examining Existing Disparities. The Extractive Industries and Society, 3, 464-474.

[29] Anselin, L. (2002) Multidimensional Poverty. Theory, Québec, Institut de Mathématique Gauss, 33 p.

[30] OECD (2008) Handbook on Constructing Composite Indicators. Methodology and User Guide, Paris, 158 p.

[31] Lemière, S. and Marc, C. (2006) Qualité des emplois et genre: Les effets croisés des statuts et des horaires de travail. Centre d'Economie de la Sorbonne, Paris, 29 p.

[32] Cramer, J.S. (2003) Logit Models from Economics and Other Fields. Cambridge University Press, Cambridge. https://doi.org/10.1017/CBO9780511615412

[33] Berkson, J. (1944) Application of the Logistic Function to Bio-Assay. Journal of the American Statistical Association, 39, 357-365. https://doi.org/10.1080/01621459.1944.10500699

[34] Cameron, A.C. and Trivedi, P.K. (2010) Microeconometrics Using Stata. Stata Press, College Station.

[35] Greene, W.H. (2012) Econometric Analysis. 7th Edition, Prentice Hall, Upper Saddle River.

[36] Andersen, E.B. (1970) Asymptotic Properties of Conditional Maximum Likelihood Estimators. Journal of the Royal Statistical Society, Series B, 32, 283-301. https://doi.org/10.1111/j.2517-6161.1970.tb00842.x

[37] Chamberlain, G. (1980) Analysis of Covariance with Qualitative Data. Review of Economic Studies, 47, 225-238. https://doi.org/10.2307/2297110

[38] Breslow, N.E. and Day, N.E. (1987) Statistical Methods in Cancer Research: Vol. 2 The Design and Analysis of cohort Studies. IARC, Lyon.

[39] Hosmer, D.W. and Lemeshow, S. (2000) Applied Logistic Regression. 2nd Edition, Wiley, New York. https://doi.org/10.1002/0471722146

[40] Rakotomalala, R. (2011) Pratique de la regression logistique: Régression Logistique Binaire et Polytomique. Université Lumière Lyon, Lyon.

[41] Tolonen, A. (2015) Local Industrial Shocks, Female Empowerment and Infant Health: Evidence form Africa's Gold Mining Industry. Job Market Paper.

[42] Beaman, L., Chattopadhyay, R., Duflo, E., Pande, R. and Topalova, P. (2009) Powerful Women: Does Exposure Reduce Bias? Quarterly Journal of Economics, 124, 1497-1540. https://doi.org/10.1162/qjec.2009.124.4.1497 
[43] Qian, N. (2008) Missing Women and the Price of Tea in China: The Effect of Sex-Specific Earnings on Sex Imbalance. Quarterly Journal of Economics, 123, 1251-1285. https://doi.org/10.1162/qjec.2008.123.3.1251

[44] Adair, P. and Bellache, Y. (2012) Emploi et secteur informels en Algérie: Déterminants, segmentation et mobilité de la main-d'œuvre. Région et Développement $\mathrm{n}^{\circ}$ 35-2012.

[45] Kuepie, M., Nordman, C.J. and Roubaud, F. (2009) Education and Earnings in Urban West Africa. Journal of Comparative Economics, 37, 491-515. https://doi.org/10.1016/j.jce.2008.09.007

[46] Rankin, Sandefur and Teal (2010) Learning \& Earning in Africa: Where Are the Returns to Education High? CSAE/WPS.

[47] Robert Wood Johnson Foundation (RWJF) (2009) Education Matters for Health. Issue Brief 6: Education and Health.

http://www.commissiononhealth.org/PDF/c270deb3-ba42-4fbd-baeb-2cd65956f00e ЦIssue\%20Brief\%206\%20Sept\%2009\%20-\%20Education\%20and\%20Health.pdf

[48] Berniell, M.I. and Sanchez, P.C. (2011) Overview of Time Use Data Used for Analysis of Gender Differences in Time Use Patterns. Background Paper for the World Development Report.

[49] Autesserre, S. (2012) Dangerous Tales: Dominant Narratives on the Congo and Their Unintended Consequences. African Affairs, 111, 202-222. https://doi.org/10.1093/afraf/adr080

[50] Eftimie, A., Heller, K. and Strongman, J. (2009) Gender Dimensions of the Extractive Industries: Mining for Equity. The World Bank, Washington DC.

[51] Potter, C. and Lupilya, A.C. (2016) You Have Hands, Make Use of Them! Child Labour in Artisanal and Small-Scale Mining in Tanzania. Journal of International Development, 28, 1013-1028. https://doi.org/10.1002/jid.3245

[52] Bashwira, M.-R., Cuvelier, J., Hilhorst, D. and Van der Haar, G. (2013) Not Only a Man's World: Women's Involvement in Artisanal Mining in Eastern DRC. Resources Policy, 40, 109-116. https://doi.org/10.1016/j.resourpol.2013.11.002

[53] Teschner, B. (2014) “Orpaillage Pays for Everything”: How Artisanal Mining Supported Rural Institutions Following Mali’s Coup d'Etat. Futures, 62, 140-150. https://doi.org/10.1016/j.futures.2014.04.016 


\section{Appendices}

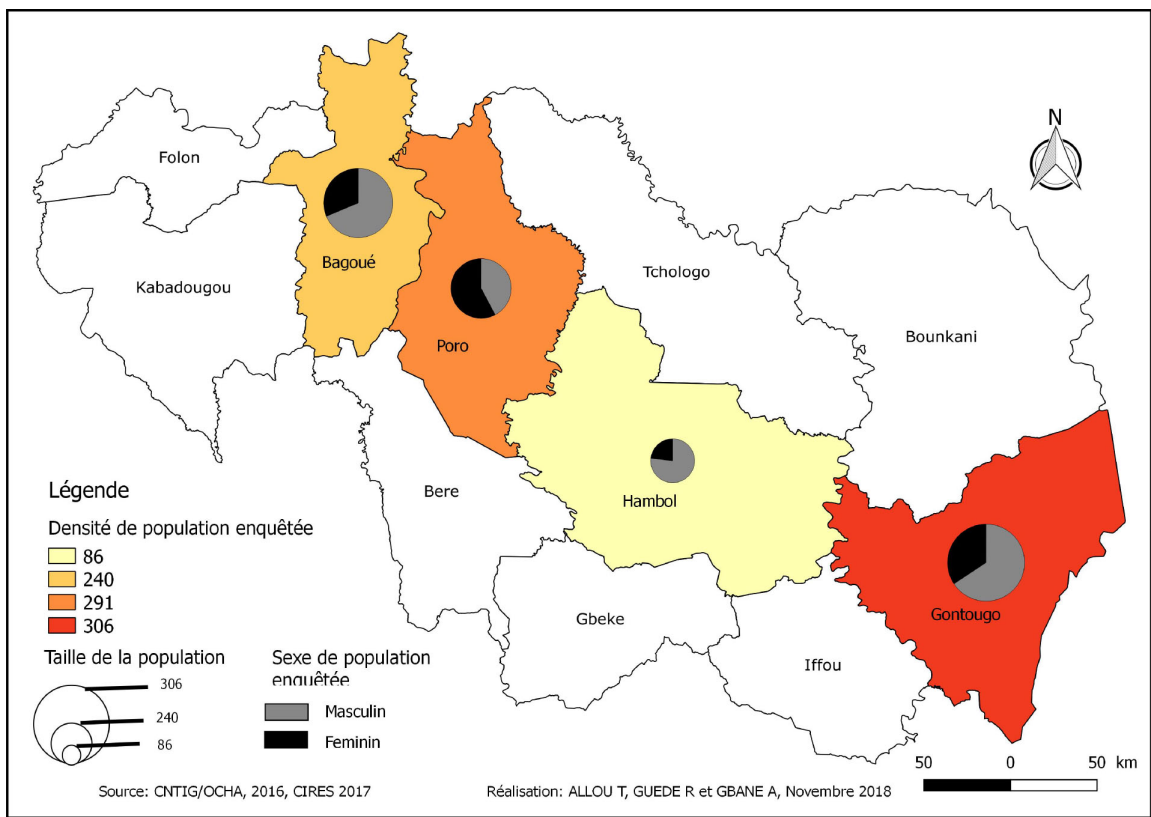

Appendix 1. Density of population surveyed. Source: Authors, from CIRES/IDRC GROW 2016 project.

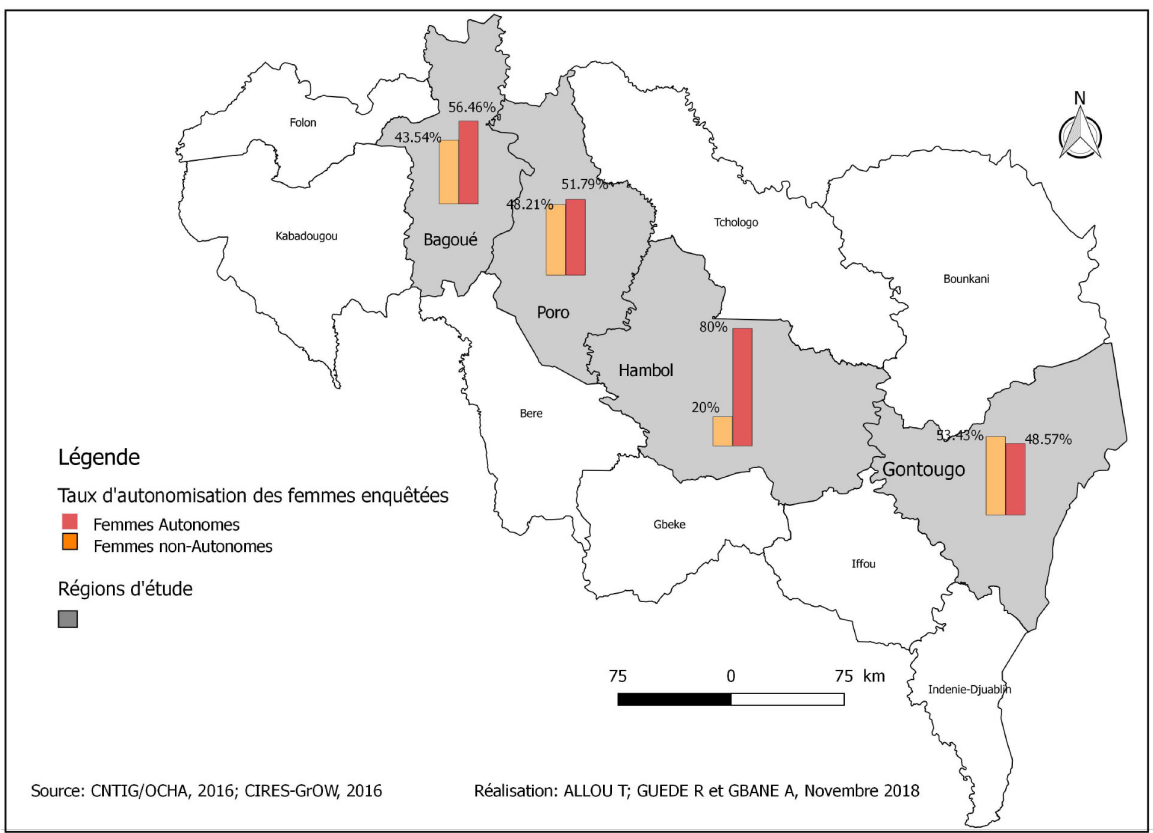

Annex 2. Women's surveyed empowerment rate. Source: Authors, from CIRES/IDRC GROW 2016 project. 
Appendix 3. Histogram of eigenvalues empowerment at household level.

\begin{tabular}{ccccc}
\hline \multicolumn{2}{c}{ Trace of matrix: } & \multicolumn{2}{c}{2.00000} & \\
\hline Number & eigenvalues & Corrected eigenvalue & Percentage & Cumulative percentage \\
\hline 1 & 0.4548 & 0.182 & 44.84 & 44.84 \\
2 & 0.4086 & 0.142 & 34.99 & 79.83 \\
3 & 0.2198 & 0.032 & 7.88 & 87.71 \\
4 & 0.1998 & 0.025 & 6.16 & 93.87 \\
5 & 0.1542 & 0.012 & 2.96 & 96.83 \\
6 & 0.124 & 0.006 & 1.48 & 98.31 \\
7 & 0.1134 & 0.004 & 0.99 & 99.29 \\
8 & 0.0946 & 0.002 & 0.49 & 99.78 \\
9 & 0.0693 & $4.13 \mathrm{E}-04$ & 0.10 & $9.99 \mathrm{E}+01$ \\
10 & 0.0647 & $2.39 \mathrm{E}-04$ & 0.06 & $9.99 \mathrm{E}+01$ \\
11 & 0.0581 & $7.27 \mathrm{E}-05$ & 0.02 & $1.00 \mathrm{E}+02$ \\
12 & 0.0385 & $1.47 \mathrm{E}-04$ & 0.04 & $1.00 \mathrm{E}+02$ \\
\hline
\end{tabular}

Source: Authors simulation, from CIRES/IDRC - GROW 2016 project. 
Appendix 4. Description of classes empowerment in household.

\begin{tabular}{|c|c|c|c|c|c|}
\hline Variables labels & $\begin{array}{l}\text { Characteristic } \\
\text { terms }\end{array}$ & $\begin{array}{c}\% \\
\text { MOD/CLA }\end{array}$ & $\begin{array}{c}\% \\
\text { CLA/MOD }\end{array}$ & Value-Test & Probability \\
\hline $\begin{array}{l}\text { Support of } \\
\text { communication costs }\end{array}$ & $\mathrm{C} 38=\mathrm{Yes}$ & 99.59 & 96.03 & 19.13 & 0.000 \\
\hline Support for transport costs & $\mathrm{C} 35=$ Yes & 100.00 & 93.46 & 18.29 & 0.000 \\
\hline Support for equipment costs & $\mathrm{C} 41=\mathrm{Yes}$ & 97.12 & 95.94 & 18.06 & 0.000 \\
\hline Supports health expenses & $\mathrm{C} 29=\mathrm{Yes}$ & 99.59 & 93.44 & 18.03 & 0.000 \\
\hline Supports food expenses & $\mathrm{C} 32=\mathrm{Yes}$ & 96.30 & 95.90 & 17.77 & 0.000 \\
\hline $\begin{array}{l}\text { Assumption of electricity and } \\
\text { water expenses }\end{array}$ & $\mathrm{C} 44=$ Yes & 92.18 & 95.73 & 16.51 & 0.000 \\
\hline $\begin{array}{l}\text { Support education for } \\
\text { expenses }\end{array}$ & $\mathrm{C} 47=\mathrm{Yes}$ & 89.30 & 96.44 & 16.13 & 0.000 \\
\hline Fields & $\mathrm{C} 17=\mathrm{Yes}$ & 27.98 & 90.67 & 5.27 & 0.000 \\
\hline Earth & $\mathrm{C} 16=\mathrm{Yes}$ & 23.05 & 93.33 & 5.19 & 0.000 \\
\hline Television & $\mathrm{C} 12=\mathrm{Yes}$ & 45.27 & 82.09 & 4.89 & 0.000 \\
\hline Internet & $\mathrm{C} 15=\mathrm{Yes}$ & 13.58 & 100.00 & 4.87 & 0.000 \\
\hline Radio & $\mathrm{C} 13=\mathrm{Yes}$ & 39.09 & 82.61 & 4.51 & 0.000 \\
\hline Farm & $\mathrm{C} 18=$ Yes & 9.88 & 100.00 & 3.99 & 0.000 \\
\hline Borrowing & $\mathrm{C} 20=$ Yes & 20.58 & 86.21 & 3.55 & 0.000 \\
\hline Saving & $\mathrm{C} 19=\mathrm{Yes}$ & 25.93 & 80.77 & 3.02 & 0.001 \\
\hline
\end{tabular}

\begin{tabular}{|c|c|c|c|c|c|}
\hline \multicolumn{6}{|c|}{ Class: CLASS $2 / 2$ (a workforce: 124 - Percentage: 33.79 ) } \\
\hline Libellés des variables & $\begin{array}{c}\text { Modalités } \\
\text { caractéristiques }\end{array}$ & $\begin{array}{c}\% \\
\text { MOD/CLA }\end{array}$ & $\begin{array}{c}\% \\
\text { CLA/MOD }\end{array}$ & Value-Test & Probability \\
\hline $\begin{array}{l}\text { Support of communication } \\
\text { costs }\end{array}$ & $\mathrm{C} 38=\mathrm{No}$ & 91.94 & 99.13 & 19.13 & 0.000 \\
\hline Support for transport costs & $\mathrm{C} 35=\mathrm{No}$ & 86.29 & 100.00 & 18.29 & 0.000 \\
\hline Support for equipment costs & $\mathrm{C} 41=\mathrm{No}$ & 91.94 & 94.21 & 18.06 & 0.000 \\
\hline Supports health expenses & $\mathrm{C} 29=\mathrm{No}$ & 86.29 & 99.07 & 18.03 & 0.000 \\
\hline Supports food expenses & $\mathrm{C} 32=\mathrm{No}$ & 91.94 & 92.68 & 17.77 & 0.000 \\
\hline $\begin{array}{l}\text { Assumption of electricity } \\
\text { and water expenses }\end{array}$ & $\mathrm{C} 44=\mathrm{No}$ & 91.94 & 85.71 & 16.51 & 0.000 \\
\hline $\begin{array}{l}\text { Support education for } \\
\text { expenses }\end{array}$ & $\mathrm{C} 47=\mathrm{No}$ & 93.55 & 81.69 & 16.13 & 0.000 \\
\hline Fields & $\mathrm{C} 17=\mathrm{No}$ & 94.35 & 40.07 & 5.27 & 0.000 \\
\hline Earth & $\mathrm{C} 16=\mathrm{No}$ & 96.77 & 39.09 & 5.19 & 0.000 \\
\hline Television & $\mathrm{C} 12=\mathrm{No}$ & 80.65 & 42.92 & 4.89 & 0.000 \\
\hline Internet & $\mathrm{C} 15=\mathrm{No}$ & 100.00 & 37.13 & 4.87 & 0.000 \\
\hline Radio & $\mathrm{C} 13=\mathrm{No}$ & 83.87 & 41.27 & 4.51 & 0.000 \\
\hline Farm & $\mathrm{C} 18=\mathrm{No}$ & 100.00 & 36.15 & 3.99 & 0.000 \\
\hline Borrowing & $\mathrm{C} 20=\mathrm{No}$ & 93.55 & 37.54 & 3.55 & 0.000 \\
\hline Saving & $\mathrm{C} 19=\mathrm{No}$ & 87.90 & 37.72 & 3.02 & 0.001 \\
\hline
\end{tabular}

Source: Authors simulation, from CIRES/IDRC - GROW 2016 project. 
Appendix 5. Descriptionof variables.

\begin{tabular}{|c|c|c|c|c|c|c|}
\hline & Variables & Obs & Mean & Std. Dev. & Min & Max \\
\hline \multirow{6}{*}{$\begin{array}{l}\text { Variables used for } \\
\text { determinants of } \\
\text { employability in artisanal } \\
\text { mining sector }\end{array}$} & $\begin{array}{l}\text { Be active in artisanal } \\
\text { mining sector }\end{array}$ & 367 & 0.779 & 0.415 & 0 & 1 \\
\hline & Place of residence & 367 & 1.485 & 0.5 & 1 & 2 \\
\hline & Age & 367 & 2.455 & 0.794 & 1 & 3 \\
\hline & $\begin{array}{c}\text { Status of the head of } \\
\text { household }\end{array}$ & 367 & 0.507 & 0.501 & 0 & 1 \\
\hline & Educational level & 367 & 1.643 & 0.48 & 1 & 2 \\
\hline & Migration status & 367 & 0.207 & 0.406 & 0 & 1 \\
\hline \multirow{9}{*}{$\begin{array}{l}\text { Variables used in } \\
\text { estimating the impact of } \\
\text { mining activities on } \\
\text { Women's Economic } \\
\text { Empowerment }\end{array}$} & Level of empowerment & 367 & 0.662 & 0.474 & 0 & 1 \\
\hline & Income quintile & 919 & 3.193 & 1.414 & 1 & 5 \\
\hline & Feeling safe at work & 919 & 1.398 & 0.49 & 1 & 2 \\
\hline & Affordable work & 919 & 0.146 & 0.353 & 0 & 1 \\
\hline & $\begin{array}{l}\text { Socio-professional } \\
\text { category }\end{array}$ & 602 & 6.61 & 2.483 & 2 & 9 \\
\hline & $\begin{array}{l}\text { Frequency of payment of } \\
\text { remuneration }\end{array}$ & 884 & 2.335 & 1.231 & 1 & 5 \\
\hline & Volume of working hours & 919 & 42.422 & 20.158 & 2 & 99 \\
\hline & $\begin{array}{c}\text { Source of information on } \\
\text { the job offer }\end{array}$ & 919 & 0.905 & 0.293 & 0 & 1 \\
\hline & Type of contract & 919 & 2.285 & 0.823 & 1 & 3 \\
\hline
\end{tabular}


Appendix 6. Test Pearson or Hosmer-Leme show goodness-of-fit test

Modèle 1

Logistic model for ext, goodness-of-fit test

number of observations $=$

number of covariate patterns $=$

Pearson $\operatorname{chi} 2(18)=$
64.81

Prob $>$ chi $2=$
367

25

0.0000

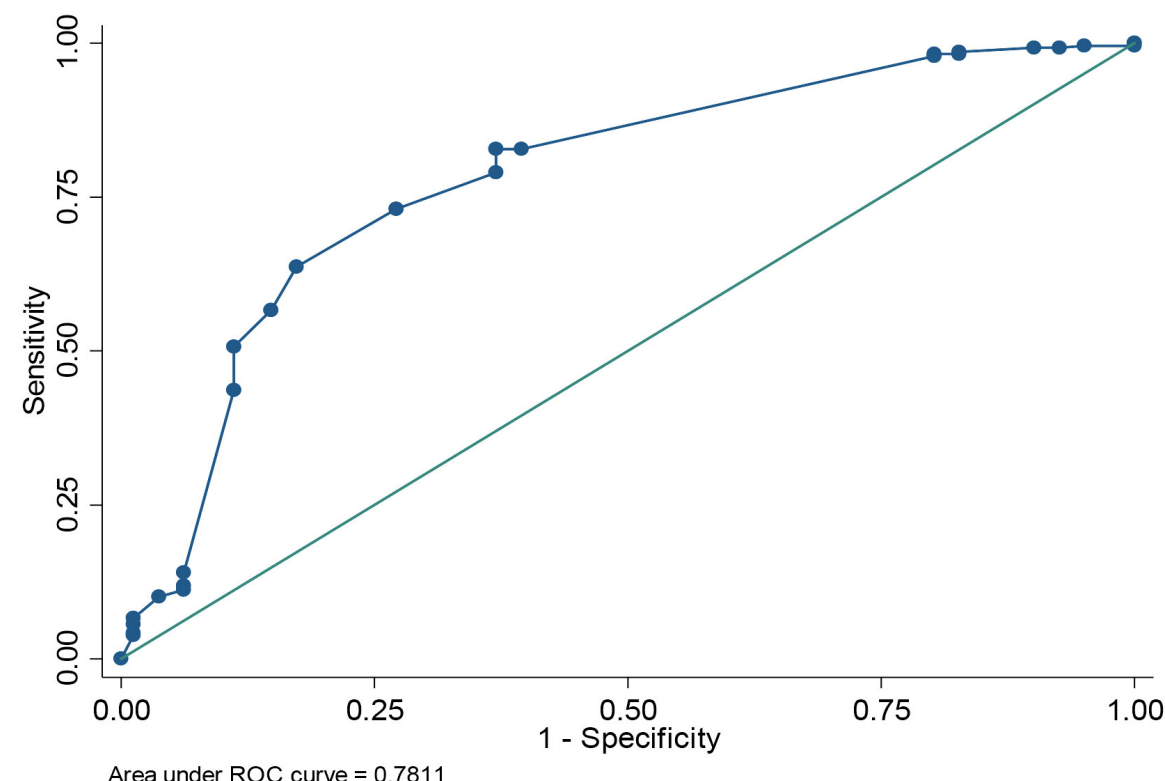

. estat classification

Logistic model for ext

\begin{tabular}{|c|c|c|c|}
\hline Classified | & $\begin{array}{l}--\operatorname{Tr} \\
D\end{array}$ & & Total \\
\hline+ & 281 & 65 & 346 \\
\hline - & 5 & 16 & 21 \\
\hline Total & 286 & 81 & 367 \\
\hline
\end{tabular}

Classified + if predicted $\operatorname{Pr}(\mathrm{D}) \geq 0.5$

True $\mathrm{D}$ defined as ext $!=0$

Sensitivity

Specificity

Positive predictive value

Negative predictive value

$$
\begin{array}{cc}
\operatorname{Pr}(+\mid \mathrm{D}) & 98.25 \% \\
\operatorname{Pr}(-\mid \sim \mathrm{D}) & 19.75 \% \\
\operatorname{Pr}(\mathrm{D} \mid+) & 81.21 \% \\
\operatorname{Pr}(\sim \mathrm{D} \mid-) & 76.19 \%
\end{array}
$$




\begin{tabular}{lll} 
False + rate for true $\sim \mathrm{D}$ & $\operatorname{Pr}(+\mid \sim \mathrm{D})$ & $80.25 \%$ \\
False - rate for true $\mathrm{D}$ & $\operatorname{Pr}(-\mid \mathrm{D})$ & $1.75 \%$ \\
False + rate for classified + & $\operatorname{Pr}(\sim \mathrm{D} \mid+)$ & $18.79 \%$ \\
False - rate for classified - & $\operatorname{Pr}(\mathrm{D} \mid-)$ & $23.81 \%$ \\
\hline- & & $80.93 \%$
\end{tabular}

\section{MODELE 2}

Logistic model for y, goodness-of-fit test

number of observations =

number of covariate patterns =

$$
\text { Pearson chi } 2(154)=\begin{array}{r}
5203.52 \\
\text { Prob }>\text { chi } 2=
\end{array}
$$

170

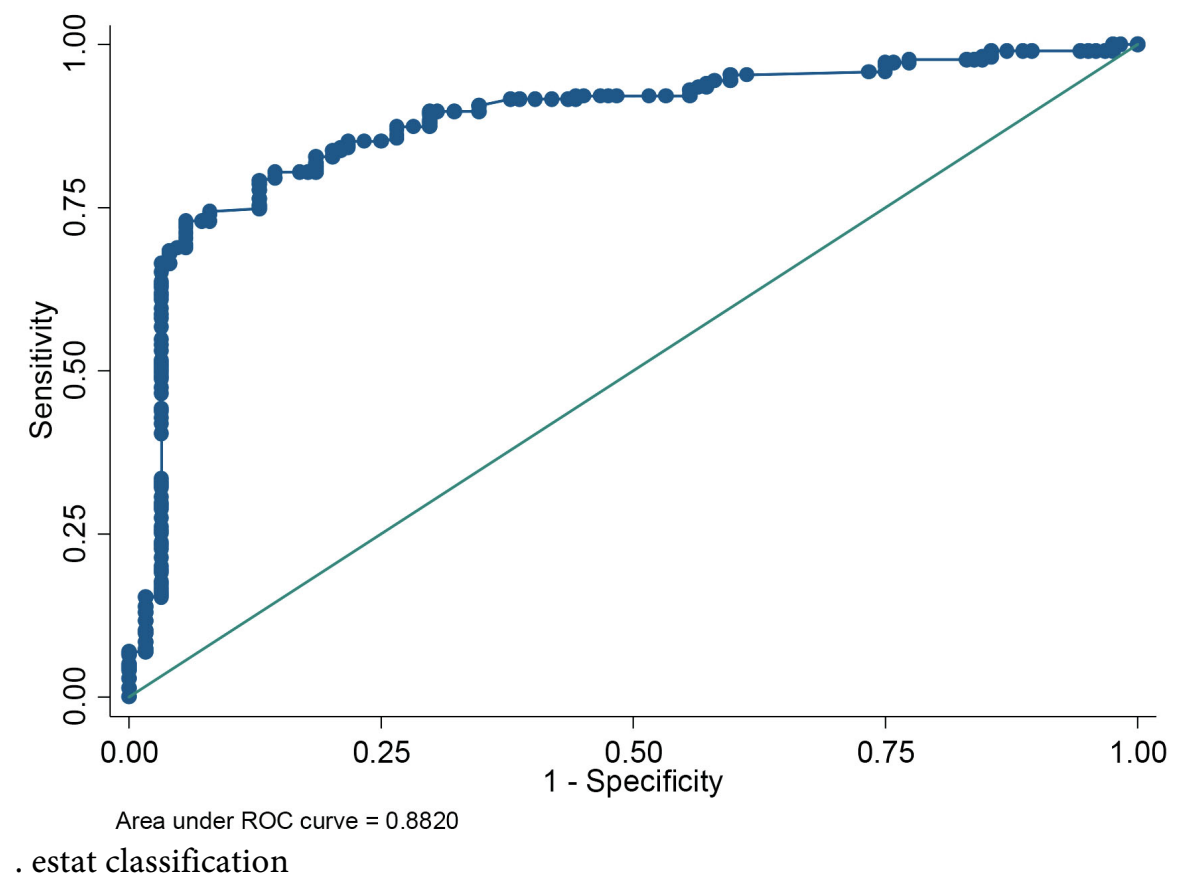

\begin{tabular}{|c|c|c|c|}
\hline Classified | & $\mathrm{D}$ & $\sim \mathrm{D}$ & Total \\
\hline+ & 1665 & 330 & 1995 \\
\hline- & 270 & 910 & 1180 \\
\hline
\end{tabular}

Logistic model for $\mathrm{y}$ 


Total | $1935 \quad 1240 \mid$

Classified + if predicted $\operatorname{Pr}(\mathrm{D}) \geq 0.5$

True $\mathrm{D}$ defined as $\mathrm{y} !=0$

\begin{tabular}{lcc} 
Sensitivity & $\operatorname{Pr}(+\mid \mathrm{D})$ & $86.05 \%$ \\
Specificity & $\operatorname{Pr}(-\mid \sim \mathrm{D})$ & $73.39 \%$ \\
Positive predictive value & $\operatorname{Pr}(\mathrm{D} \mid+)$ & $83.46 \%$ \\
Negative predictive value & $\operatorname{Pr}(\sim \mathrm{D} \mid-)$ & $77.12 \%$ \\
\hline False + rate for true $\sim \mathrm{D}$ & $\operatorname{Pr}(+\mid \sim \mathrm{D})$ & $26.61 \%$ \\
False - rate for true D & $\operatorname{Pr}(-\mid \mathrm{D})$ & $13.95 \%$ \\
False + rate for classified + & $\operatorname{Pr}(\sim \mathrm{D} \mid+)$ & $16.54 \%$ \\
False - rate for classified - & $\operatorname{Pr}(\mathrm{D} \mid-)$ & $22.88 \%$
\end{tabular}

Correctly classified

$81.10 \%$ 